\title{
RADIOCARBON EVIDENCE FOR HOLOCENE RECHARGE OF GROUNDWATER, WESTERN DESERT, EGYPT
}

\author{
C VANCE HAYNES \\ Department of Geosciences, The University of Arizona, \\ Tucson, Arizona 85721 \\ and \\ HERBERT HAAS \\ Department of Geological Sciences, \\ Southern Methodist University, Dallas, Texas 75275
}

\begin{abstract}
During Pleistocene pluvial precipitation was sufficient for the maintenance of groundwater supported lakes and for the accumulation of playa lakes in wind-scoured depressions during the early Holocene pluvial. At places where ground water reaches near to the surface, wells (birs) have been dug and maintained in historic times. These birs have been used as sampling sites for water analyses, including carbon-14 levels, carbon and oxygen stable isotope ratios, tritium concentrations, and chemical data.

All the waters from birs analyzed to date produced apparent radiocarbon ages ranging from late historic to early Holocene, and tritium analyses on some of these indicate no recharge during the Atomic age.

Sources of error for the radiocarbon analyses, including exchange with atmospheric $\mathrm{CO}_{2}$, respiration by plant roots, and contact with carbonates of considerably older age, were evaluated. None of these factors have such an extrene impact on the measurements as to render the result invalid. Two trends revealed by these data are an increase in apparent age from northwest to southwest and with subsequent extractions at the same site where the hand-dug well was bailed out and sampled four times within two days.

We conclude that recharge of shallow ground water occurred in early Holocene time, and some recharge of deeper aquifers may have occurred where infiltration paths permitted. Some recharge occurred in late Holocene (post pluvial) time, but the net trend has been toward hyper-aridity that characterizes the area today.
\end{abstract}

\section{INTRODUCTION}

The concept of a static water table beneath the Libyan Desert was proposed by Lyons (1908) and defined by Ball (1927). The model developed by Ball was extended to the Sudan and updated by Sandford (1935) and further discussed by Hellstrom (1940), Murray (1952) and Ezzat (1974). In all of these models the elevations of the water contours were based upon near-surface exposures at desert watering places (birs), where water can be found in hand-dug wells at a meter or two depth, as well as in the deeper bores in the oases. The shallow depth of water at the birs was assumed to be a result of the lowering of the desert surfaces by wind to that of the water table.

The source of the ground water was believed to have been Pleistocene rains that fell in higher mountainous regions in Sudan and Chad during past pluvials (Ball, 1927). Support for the Pleistocene age came with the radiocarbon analyses of deep well and artesian water of the Egyptian oases, indicating apparent ages of 20,000 to $30,000 \mathrm{BP}$, but recharge via the oases' depressions was suggested by Münnich and Vogel (1962) in their pioneering work.

From the prehistoric archaeologic record of the Western Desert uncovered by Caton-Thompson and Gardner (1932), Myers (1939), and 
most recently by the Combined Prehistoric Expeditions (Wendorf and others, 1976; 1977) the record of changing climate during the late Quaternary, although still incomplete, is known in general terms. During late Acheulian times (ca 200,000 $\pm 100,000 \mathrm{BP}$ ) wetter climates with numerous springs, central African faunas, and Acheulian hunters occupied much of the Western Desert but disappeared altogether with the onset of a hyper-arid period marked by wind erosion and dune deposition. Another period of human occupation was during the Middle Paleolithic when central African game animals were again in the Western Desert, pursued by Mousterian and Aterian peoples around lakes that dotted the area 100,000 to 25,000 or more years ago.

Another episode of 10,000 years or more of severe drought and aeolian erosion followed. The area was not again occupied until the Neolithic pluvial in the early Holocene when Terminal Paleolithic and Neolithic hunters, pastoralists, and incipient farmers spread over the desert between 9500 and 5000 years ago. During this time, there were at least three phases of playa lakes during which a great number of depressions accumulated slope-wash sediments and water with still-stands significant enough to form shore features. But by $5000 \mathrm{BP}$, with essentially no rainfall, the lakes dried up, and wind erosion under hyper-arid conditions has been the dominant process since then. Today, in an area of $400,000 \mathrm{sq} \mathrm{km}$, there are only eight places known where water may be found by digging shallow wells in sand. Many such wells were the traditional watering places of caravans that crossed this vast desert before the 20th century, and a few are still used by an occasional caravan from Kharga Oasis to northern Sudan to collect natron. These lie along the Darb el Arba'in (fig 1), the most famous of the ancient routes of the slave trade in Egypt and Sudan (Shaw, 1929).

On the basis of present conditions in Sudan and northern Egypt, one of us has estimated annual rainfall during the Neolithic pluvial to have been at least $200 \mathrm{~mm}$ (Haynes, in press). Therefore, it is reasonable to investigate the possibility that significant Holocene recharge may have occurred in local areas, especially those known to have shallow ground water. If this water is of Holocene age, elevations on the static water table will have to be revised and prehistoric occupations of the Western Desert would not have been wholly dependent upon pluvial lakes for water. For this purpose, during our 1977 and 1978 field seasons, we collected water samples at several birs including some of those used by Ball in his mapping of the static water table.

\section{Procedure}

At each well, all less than $2 \mathrm{~m}$ deep, the water was bailed out and allowed to settle until it was reasonably clear of suspended matter. One, two, or three 20 liter jugs, depending upon time and yield, were filled to overflowing in order to decant any floating organic matter. After recording $\mathrm{pH}$ and temperature ca $8 \mathrm{gm}$ of ferrous ammonium sulfate, $25 \mathrm{gm}$ of sodium hydroxide, and $47 \mathrm{gm}$ of barium chloride were added 
to each jug to co-precipitate metallic hydroxides and barium carbonate after a technique approved by the International Atomic Energy Agency (Pearson, pers commun).

After agitation, sometimes including motor transportation to camp, each jug was inverted and the precipitate allowed to settle into the neck area where it could be tapped off through a petcock fitted to each cap. The precipitate, then in as many $500 \mathrm{ml}$ plastic jars as necessary, would be further consolidated by either decantation of the supernatant liquid or by filtration on a buchner funnel fitted with a cap, ascarite air filter, and squeeze bulb to produce a partial vacuum.

In the laboratory, the $\mathrm{CO}_{2}$ is released by acid hydrolysis and analyzed for carbon isotopes in the standard manner. During the second season, separate $500 \mathrm{ml}$ samples were taken for tritium and stable isotope analyses. In addition to water samples, several desiccated, wind-abraded, but rooted dead plants were collected in order to determine if their germination was promoted by Atomic age rain. Salsola baryosma, a

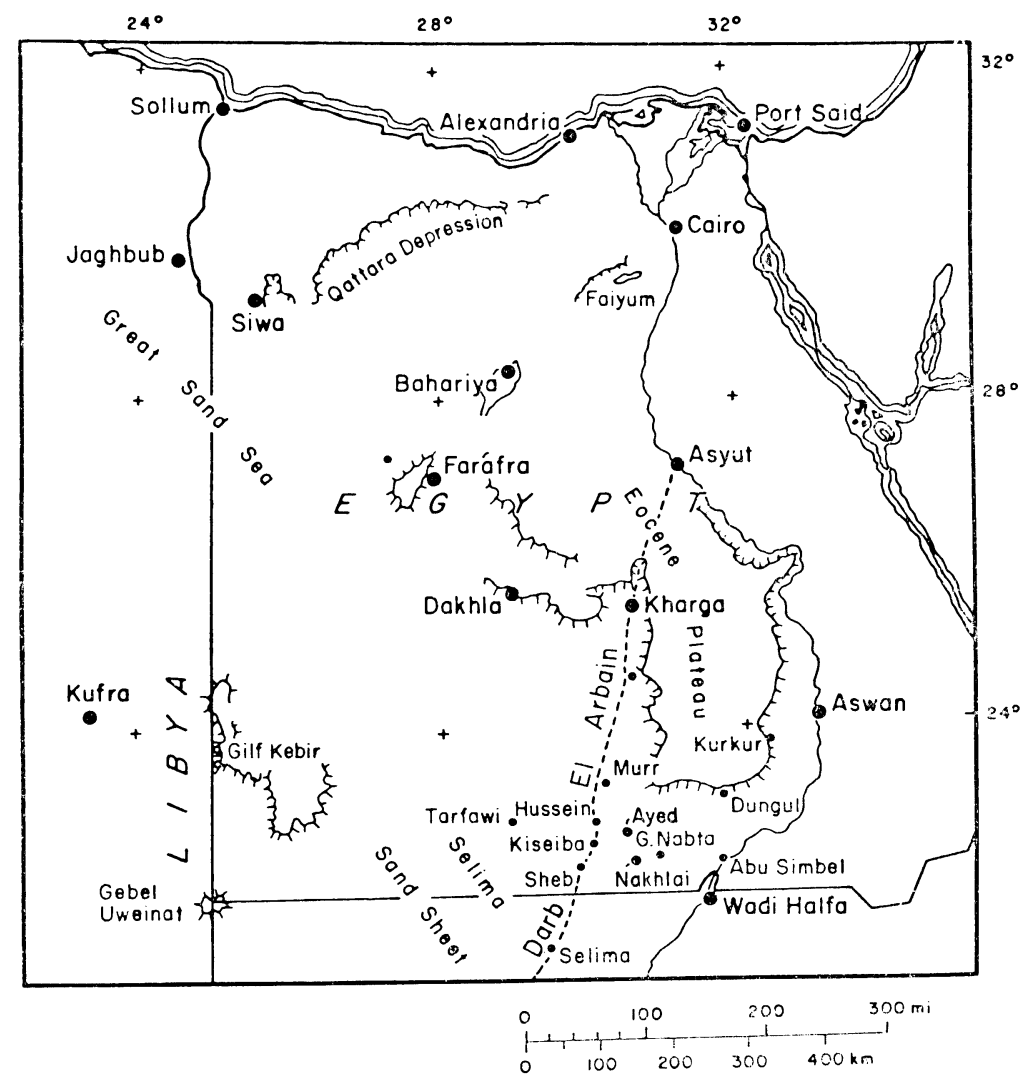

Fig 1. Map of Egypt showing the location of desert wells (birs) and major oases and towns. 
tumbleweed-like perennial plant that persists for only a year or so after a single rainstorm, should reveal ${ }^{14} \mathrm{C}$ in excess of 100 percent modern if germinated since 1960 (Nydal and Lövseth, 1970). Our results are presented in table 1 .

Because our main objective is to determine the origin and age of shallow ground water in relation to pluvial climates and human occupation of the area and to communicate our findings to a wide interdisciplinary audience, we prefer to speak in terms of "apparent" age (uncorrected) rather than parts per mill with respect to the standards so familiar to isotope geochemists. It should be understood that the errors in apparent ages commonly exceed the standard errors.

As a test of our method, water from the deep aquifer in Kharga (West Balat well) was analyzed for radiocarbon (table 1), and the apparent Pleistocene age is in good agreement with values determined by Münnich and Vogel (1962) on nearby wells from the same aquifer.

\section{Description of birs}

Bir Tarfawi and Tarfawi West, sometimes mistakenly referred to as Bir Sahara (Wendorf and others, 1977), are two small vegetated basins $11 \mathrm{~km}$ apart and $60 \mathrm{~km}$ west of the Darb el Arba'in (fig 1). At least twice during the Pleistocene, these shallow basins held lakes and were inhabited by people and game animals (Wendorf and others, 1976; 1977), but today, one must dig a meter or two in the lower parts of the basins in order to find water beneath the dune sand that partially fills them.

The Pleistocene deposits are calcreted dune sands penetrated by spring vents with late Acheulian artifacts, overlain by more dune sands with buried soils, iron staining, interbedded lacustrine precipitates, and artifacts of Middle Paleolithic (Mousterian-Aterian) age. The calcrete extends for $20 \mathrm{~km}$ or more in all directions and is believed to be set into a large but shallow depression within sandstone of the Nubia Formation and bounded on the east by the El Tawila granite (Issawi, 1971). The subsurface geology is unknown, but Sahara Well, the original place to which the name Bir Sahara was applied by Beadnell (1931), 30km southwest of Tarfawi West, penetrated $17.5 \mathrm{~m}$ of sandstone before encountering water at $245 \mathrm{~m}$ asl, and the well at Bir Misaha, $110 \mathrm{~km}$ southwest of Sahara Well, penetrated $45 \mathrm{~m}$ of dry sand and $22 \mathrm{~m}$ of moist sand before reaching water at $262 \mathrm{~m}$ asl (Beadnell, 1931).

Projecting the Sahara well level to Bir Tarfawi and Tarfawi West (246m) suggests that the shallow ground water there may be due to the static water table as proposed by Ball (1927), but the radiocarbon date of $290 \pm 70$ вP (SMU-433) (table 1) indicates recharge in modern time.

Bir Abu el Hussein (well of the foxes) was originally nothing more than a small hole excavated to water by desert foxes in aeolian sand in an unvegetated area beside an outcroping of granite on the Darb el Arba'in. In recent years, the General Desert Development Organization deepened the well and cased it with 4 open-ended oil drums welded 


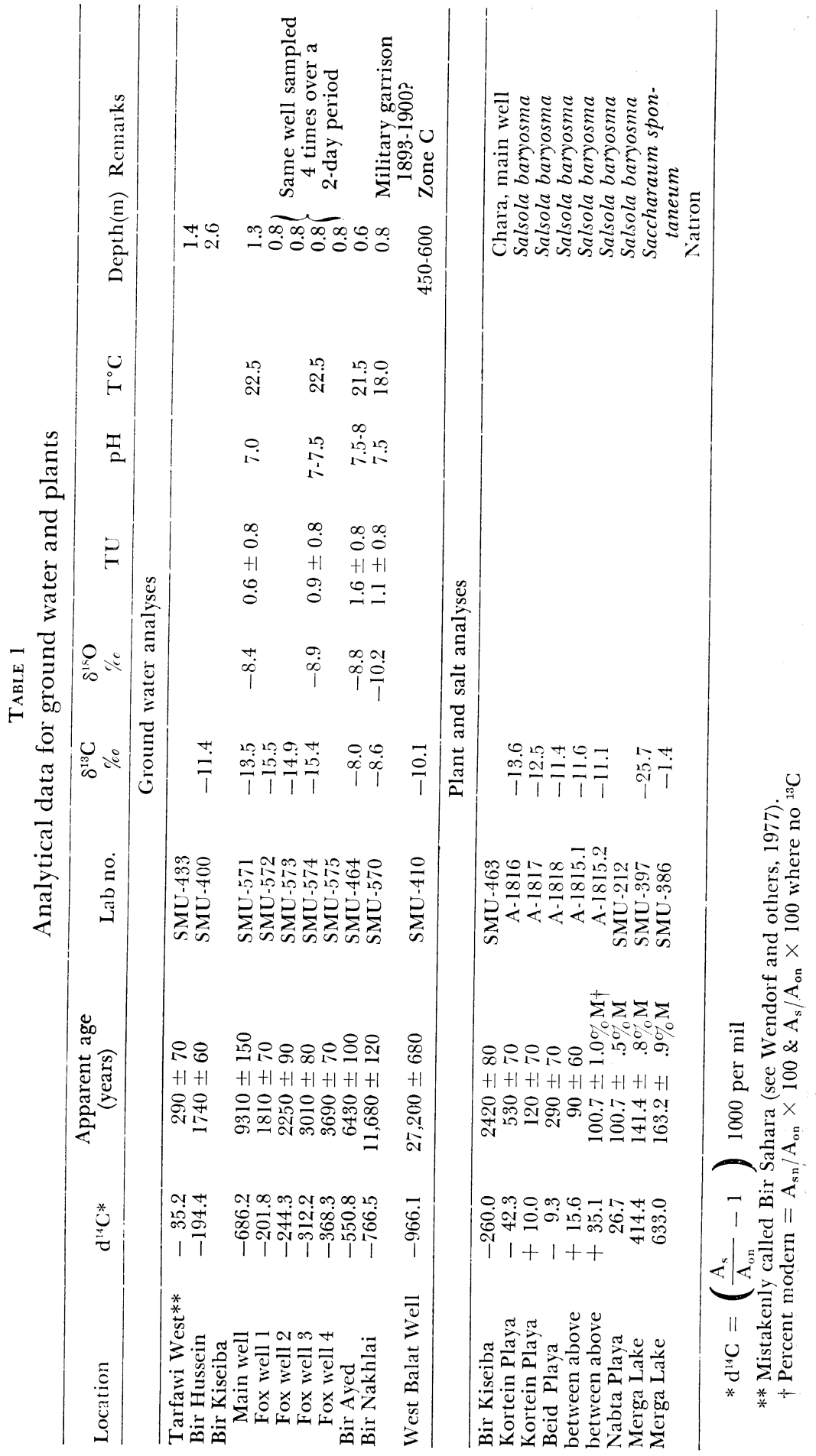


together and extending $0.7 \mathrm{~m}$ above the surface, presumably to keep out animals and sand. A radiocarbon date of $1740 \pm 60$ BP (SMU-400) (table 1) indicates recharge in historic time of what is probably a perched aquifer (Issawi, 1971).

Approximately $20 \mathrm{~km}$ south of Bir Hussein lies Bir Kiseiba, a major watering place on the Darb el Arba'in. The small grove of date and dom palms create a picturesque miniature oasis at the base of a $40 \mathrm{~m}$ escarpment along which playa mud deposits and shore features occur intermittently for $70 \mathrm{~km}$ (Haynes, Said, and El Hennawi, 1977). Numerous terminal Paleolithic and Neolithic archaeologic sites associated with the lacustrine deposits have provided charcoal samples radiocarbon dated at 9000 to $6000 \mathrm{BP}$, thus duplicating part of the pluvial climatic record discovered at Nabta playa (Wendorf and others, 1976; 1977).

The main well, an open pool approximately $2.4 \mathrm{~m}$ in diameter and $1.3 \mathrm{~m}$ below surface, contains a bottom mat of calcareous algae (cf chara) and a green filamentous algae. The walls of aeolian sand are encrusted with white efflorescent salts. In 1976, we were unable to collect a sufficient water sample but did collect chara which photosynthesizes with subaqueous $\mathrm{CO}_{2}$ (table 1). Water was collected in 1978 after a caravan of 70 camels and 10 men had watered there. The well was allowed to recover overnight and was bailed again before collecting. Radiocarbon and tritium analyses suggest Holocene recharge but no contribution from rain during the Atomic age (table 1).

A fox well in an untapped part of the bir, ca $112 \mathrm{~m}$ northwest of the main well, was enlarged and a sequence of four samples collected to test the degree of change with each extraction, presumably representing slightly deeper levels. Analyses indicated Holocene recharge with no Atomic-age contribution and an increase in apparent age with depth (table 1).

Bir Ayed, $30 \mathrm{~km}$ northeast of Bir Kiseiba, is not on any known caravan route and presumably has not been tapped in modern time. A radiocarbon date of $6430 \pm 100$ BP (SMU-464) indicates Holocene recharge.

Bir Nakhlai, on an east-west fault (Issawi, 1971) and $60 \mathrm{~km}$ east of Bir Kiseiba, is a traditional watering place on a caravan route that has not been used in this century. Its importance in the 19th century is indicated by two stone block houses built in 1893 (Gleichen, 1905) or 1894 (Comyn, 1911) to prevent use of the bir by Dervish raiding parties from Sudan. There are several places where shallow wells have been dug in recent years but a small cribbed well between the block houses was probably the main well during the Anglo-Egyptian-Dervish war. The well, covered by rotten planks and partly filled with sand and growing grass, was cleaned out and bailed before collecting. Early Holocene recharge with no Atomic-age contribution is indicated by the apparent age of 11,680 \pm 120 вр (SMU-570) (table 1). 
DISCUSSION

In evaluating the radiocarbon analyses of ground water, several sources of error must be considered. The apparent age of the shallow ground water can be as much as several thousand years older than the true age due to dilution by older sources of carbon encountered by rain water in soil zones (Tamers, 1967; Klitzsch and others, 1977). Northeast of the area sampled, calcic horizons of two weak Holocene soils were analyzed for ${ }^{14} \mathrm{C}$ as a test for pedogenic carbonates derived from limestone dust blown from the Eocene limestone plateau to the north. Apparent ages of 21,590 $\pm 180 \mathrm{BP}$ (SMU-207) and 24,680 \pm 330 BP (SMU210) indicate this source to be a significant one for pedogenic carbonates up to $100 \mathrm{~km}$ downwind of limestone outcrops (Haynes, in press). However, evidence from Holocene lake marls and tufa in the Western Desert of northern Sudan suggest that this effect may not have been significant in this area (Haynes, Mehringer, and Zaghloul, 1979). This may be due to the greater distance from limestone areas and/or to extreme deflation of soils during the hyper-arid period preceding the Neolithic pluvial.

Neither is ${ }^{14} \mathrm{C}$ dilution by ancient carbonates in the aquifer seen as a major problem in the perched aquifers because the ${ }^{13} \mathrm{C}$ values are not excessively high and because of the relatively young apparent ages despite the absence of Atomic-age water. Contamination by older carbon is probably not a significant factor although birs Nakhlai and Ayed could be exceptions.

Two mechanisms whereby ground water can be made to appear too young are exchanged with atmospheric $\mathrm{CO}_{2}$ and with $\mathrm{CO}_{2}$ from root respiration. The degree to which exchange with atmospheric $\mathrm{CO}_{2}$ may have affected our radiocarbon analyses is not known, but all samples were protected from direct contact with the atmosphere by at least $50 \mathrm{~cm}$ of sand of which the lower 25 to $30 \mathrm{~cm}$, the capillary fringe, are moist. Exchange with the atmosphere should be greatly reduced below the capillary fringe because of relatively slow rates of diffusion through sand. The uppermost layer of water, a boundary layer, would be the most affected. This layer would also be the most affected by exchange with $\mathrm{CO}_{2}$ respired from plant roots. Furthermore, the present $\mathrm{pH}$ of the waters, less than eight, is not conducive to the uptake of $\mathrm{CO}_{2}$. Our procedure of bailing before collecting was done to reduce this potential source of contamination. Under the static conditions prevailing at the wells it is unlikely that there is much mixing of the surface layer with deeper ones. Even so, it is possible that some contribution from this source exists, but the fact that the oldest apparent age came from the most shallow and root-infested well, Bir Nakhlai, suggests that contamination by modern radiocarbon is not significant enough to alter the conclusion that shallow ground water at the birs of the Western Desert is derived from precipitation during the Holocene.

The oxygen isotope data are useful in evaluating the climate under which the recharge occurred. The $\delta^{18} \mathrm{O}$ values, all similar (table 1 ), are 
typical for humid environments (IAEA, 1969 and later nos.) and preclude recharge during arid times. The value for Bir Nakhlai, somewhat lighter than the rest, may indicate a different source or age. Because of an east-west fault there (Issawi, 1971) the water may be a mixture of Holocene and Pleistocene recharge.

Two possible trends revealed by the radiocarbon data are an increase in apparent age (decrease in ${ }^{14} \mathrm{C}$ ) with depth at Bir Kiseiba and laterally from Bir Tarfawi eastward to Bir Nakhlai. The former trend could be the result of contamination by $\mathrm{CO}_{2}$ exchange or root transpiration. But, as just discussed, this is not believed to be so serious as to make Pleistocene water $(>25,000 \mathrm{BP})$ appear to be Holocene in age. We are unable to prove that the apparent ages are not somewhat younger than true ages. Thus, there is the question of whether the increase in apparent age with depth seen at Bir Kiseiba is due to contamination or to layering of recharge. For the reasons stated above, we do not believe that contamination is the main cause of this trend, and layering is consistent with the most likely model of recharge as described next.

Along the eastern side of the Kiseiba escarpment, several shallow $(<10 \mathrm{~m})$ basins occur from near Bir Ayed in the northeast and to Bir Sheb at the southwest end, and remnants of beach deposits along the scarp indicate that some of these basins may have coalesced into larger lakes in early Holocene time sometime near 9000 BP. Playa muds intermixed with aeolian sand make up the floor and in places, as at Nabta playa, are underlain by Pleistocene dunes believed to be overlying bedrock shale. Thus, with the onset of pluvial conditions, rainwater saturated the dunes and collected on the clay floor as sediments washed into the basin. With the return of arid conditions, the surface water evaporated and the lacustrine deposits suffered deflation until limited by the shallow ground water. Subsequent return to pluvial conditions would, via dune windows in the wind-scoured floor of the playa, recharge the local water table until a new lake had formed. The evidence from Nabta playa (Wendorf and others, 1976; 1977) indicates that these cyclic events occurred several times during the early Holocene, and that by $5000 \mathrm{BP}$, conditions at least as hyper-arid as today $(<1 \mathrm{~mm} / \mathrm{yr})$ had set in.

Elsewhere, such as at Bir Tarfawi and Tarfawi West, where there is no evidence of a Neolithic lake but where there is shallow groundwater of young apparent age, recharge may have been directly through the aeolian sand filling the basins. Dincer, Al-Mugrin, and Zimmerman (1974) in the Arabian Desert and Muller (1974) in the Kanen Desert, northern Chad, conclude that a significant part of the annual rainfall of ca $80 \mathrm{~mm}$ infiltrates sand dunes and constitutes the main mechanism of present recharge to the water table. Though less, this is the same order of magnitude as the $200 \mathrm{~mm}$ minimum estimated for annual precipitation in the Western Desert during the Neolithic pluvial, as stated earlier. These conclusions are compatible with both a model of recharge within the oases depressions (Knetsch and others, 1962) and the model of recharge mounds suggested by Lloyd and Farag (1978). Bagnold (1954) 
estimated $24 \mathrm{~mm}$ as the minimum rain to be effective in producing vegetation that would support temporary (gizu) grazing, but on a yearly basis, this is probably not adequate for effective recharge and certainly not for maintenance of lakes.

The apparent ages of less than 5000 BP could be due to occasional episodes of sufficient rain to cause recharge or to the contamination mechanisms discussed earlier. There are suggestions of brief episodes of increased moisture elsewhere in North Africa during late Holocene time (Street and Grove, 1976), and our analyses of Salsola baryosma indicate occasional late Holocene but pre-Atomic-age rains (table 1). Atomic-age rain was clearly indicated for Merga Lake in Sudan where the ${ }^{14} \mathrm{C}$ of recently formed sodium carbonate (natron) was $163.29 \pm 0.89$ percent modern (table 1). In the future, it would be useful to sample and analyze these untapped Holocene perched aquifers in increments from top to bottom. Inflection points in the age-depth curve could be related to climatic change.

The increase in apparent age from Tarfawi West to Bir Nakhlia could be the result of more frequent recharge westward, up the regional slope, but the maximum difference in elevation, ca $70 \mathrm{~m}$, is probably too slight to be significant in this regard. On the other hand, the Gilf Kebir Plateau farther west is several hundred meters higher and may orographically induce more recharge.

It is possible that variations in local aquifer conditions in conjunction with human usage have been more effective in producing the apparent age data than rainfall distribution which may be nearly random throughout this area (Bagnold, 1954). The very young apparent age for water from Tarfawi West indicates that the most recent recharge occurred there. Unfortunately, we do not have a tritium analysis for this sample to test if there has been Atomic-age rain.

The results from Bir Kiseiba clearly indicate the effect of human usage on the apparent ages of samples becoming older with depth. Thus, our analysis from the cribbed well at Bir Nakhlai suggests that considerable drawdown may have been imposed by the Anglo-Egyptian garrison there. A similar garrison was maintained at Bir Sheb and repulsed a Dervish raid in 1893 (Budge, 1907), but our water sample from there, unfortunately, did not contain adequate $\mathrm{HCO}_{3}=(\mathrm{pH} \approx 4)$ for analysis.

There are several possible reasons why the samples from Bir Kiseiba do not have as great an apparent age as that from Bir Nakhlai. Old water could be ascending the fault and mixing with Holocene water as suggested previously. Also, although Kiseiba lies on the Darb el Arba'in, the major caravan route, a military garrison was never stationed there, as far as we know. Furthermore, the main well today was not necessarily the main well in the past, because there are signs of several abandoned wells in the palm grove and even older ones are on the deflated playa floor outside of the grove. From our observations, the present well has 
not changed since 1974, and Bedouin guide, Ayed Marif Selim, informs us that it was excavated in 1969.

It appears, therefore, a well such as Bir Kiseiba is used until it is filled with sand, probably during a severe sand storm. There is no evidence of historic usage of Bir Ayed. Thus, the relatively old apparent age for the top of its water, compared with the young apparent age for the well at Tarfawi West, after three seasons of use by the Combined Prehistoric Expedition (Wendorf and others, 1976; 1977), may be an indication of the variation to be expected from the randomness of precipitation in a hyper-arid desert.

In order to estimate the water withdrawal at Bir Kiseiba, we assume that each camel consumes $40 \mathrm{~L}$, each human $4 \mathrm{~L}$, and the water bags are filled with $4 \mathrm{~L} / \mathrm{man} /$ day. It takes 4 days to reach Selima. For a caravan of 70 camels and 10 men en route to Selima, some $3000 \mathrm{~L}\left(3 \mathrm{~m}^{3}\right)$ would be taken on at Kiseiba no more than six times each year, or $18 \mathrm{~m}^{3} /$ year for approximately 80 years $\left(1440 \mathrm{~m}^{3}\right.$, total $)$ back to the end of the slave caravans. These may have consumed as much as 100 times this amount for the past 1000 years, although Bir Kiseiba may not have been used by all of the caravan traffic as it is today. Even so, this comes to $1.8 \times 10^{6}$ $\mathrm{m}^{3}$. Loss by evaporation from open wells is also significant depending upon how many were left open. The main well at Bir Kiseiba is approximately $5 \mathrm{~m}^{2}$ in area and the annual evaporation rate for Kharga is $6000 \mathrm{~mm}$ (Ezzat, 1974, p 4). It must be at least this much for Bir Kiseiba, therefore, indicating a minimum loss of $30 \mathrm{~m}^{3}$ per year. If four such wells were open at one place or another for a millennium, the loss would amount to $1.2 \times 10^{5} \mathrm{~m}^{3}$. An additional loss would be from transpiration of the 120 or so date and dom palms. If this were twice that due to evaporation, the total loss due to human use, evaporation, and transpiration would be $2.2 \times 10^{6} \mathrm{~m}^{3}$. The size of the reservoir at Bir Kiseiba is unknown, but a conservative estimate can be made by multiplying the $20 \mathrm{~km}^{2}$ area of the secondary depression by a minimum depth of $4 \mathrm{~m}$, or $8 \times 10^{7}$ $\mathrm{m}^{3}$. Thus, since the rise of the slave trade following the Arab invasion, there has been on the order of 3 percent depletion.

The discovery that much of the shallow ground water of the Western Desert is a relict of the Holocene pluvial is significant for understanding the factors critical to prehistoric human occupation and the chronology of the region. The earliest Holocene sites are Terminal Paleolithic, dating ca $9500 \mathrm{BP}$, and not directly associated with playa or lacustrine deposits. A more mesic environment is inferred from a paleosol on buried dunes and from the appearance of thin lamina of playa clays in the next overlying unit containing the second Terminal Paleolithic occupation (Wendorf and others, 1977). The sequence indicates rising ground water as Holocene rains infiltrated the sand-filled basins until water eventually stood at the surface. During the period of rising ground water, the desert climate changed from hyper-arid to arid, allowing man and animals to expand their ranges from central Sudan northward into the Western Desert. 
The archaeologic record shows that prehistoric people were able to subsist on shallow ground water even after the lakes had dried up, but eventually, this source too became inadequate to sustain life under hyper-arid conditions. With the introduction of camels during historic time the few remote areas of shallow ground water became accessible. But these are non-renewable resources that will not be able to withstand drawdown much beyond the present rate. Each bir is a unique ecologic system, a miniature oasis, with plants, animals and insects that are, most likely, the last relicts of the Holocene pluvial. As such, they should be considered national assets and protected accordingly.

\section{CONCLUSION}

From these investigations of the isotopic content of shallow gound water of the Western Desert, we conclude that

1) Significant recharge of shallow ground water occurred in early Holocene time. It is possible that some of this recharge may have reached the deeper aquifer wherever infiltration paths permitted.

2) Our observations support both a model of recharge within the oases depressions (Knetsch and others, 1962) and the model of recharge mounds suggested by Lloyd and Farag (1978), with the latest significant recharge occurring in Holocene time rather than late Pleistocene.

3) Some recharge has occurred in late Holocene (post-pluvial) time, but the net trend has been toward hyper-aridity.

4) Recharge at Bir Kiseiba may have occurred at the top of the perched aquifer to produce a sequence of layers, youngest toward the top.

5) Rainfall during the past 30 years, the Atomic age, has been ineffective in recharging the four birs analyzed for ${ }^{3} \mathrm{H}$.

6) If the shallow sources of ground water are perched, recharge is not likely to exceed loss until the next climatic change to pluvial conditions which is probably on the order of thousands of years from now.

7) Any plans to develop the shallow ground water beyond the present rate of consumption by caravans and occasional travelers could rapidly deplete the limited supply.

\section{ACKNOWLEDGMENTS}

This work was supported by the National Geographic Society, Smithsonian Foreign Currency program grants FR4-60094 and FC 80140100, National Science Foundation Grants GS-36959 and EAR 7710109, and was performed as part of the Combined Prehistoric Expedition sponsored by Southern Methodist University, the Polish Academy of Science, and the Geological Survey of Egypt. For this opportunity, we owe special thanks to Fred Wendorf (SMU) and Bahay Issawi (GSE). Tritium measurements were made by $\mathrm{F} J$ Pearson and $\mathrm{T}$ A Wyerman, US Geological Survey, Reston, Virginia, and oxygen isotope values were determined by Anthony Muller, University of Arizona, who made valuable suggestions toward improving the manuscript. P J Mehringer, D L Johnson, M Hinnawi, and El Sayed A Zaghloul were especially helpful in making the field work successful. 
REFERENCES

Bagnold, R A, 1954, Physical aspects of dry deserts, in Clondsley-Thompson, J L, cd, Biology of deserts, p 7-12.

Ball, J, 1927, Problems of the Libyan Desert: Geog Jour, v 70, p 21-38, 105-128, 209-224. Beadnell, H J L, 1931, Zerzura: Geog Jour, v 77, p 245-250

Budge, E A W, 1907, The Egyptian Sudan: New York, J B Lippincott Co., p 85

Caton-Thompson, G and Gardner, E W, 1932, The prehistoric geography of Kharga Oasis: Geog Jour, v 80, no. 5, p 369-409.

Comyn, D, 1911, Service and sport in the Sudan: London, John Lane, p 289-316.

Dincer, T, Al-Mugrin, and Zimmermann, V, 1974, Study of the infiltration and recharge through the sand dunes in arid zones with special reference to the stable isotopes and thermonuclear tritium: Jour Hydrology, v 23, p 79-109.

Ezzat, El Wadi El Gadid (New Valley) Project: Pt II, Hydrologic conditions, DakhlaKharga area: Cairo, Government Printing Offices, p 4.

Gleichen, Count, 1905, The Anglo-Egyptian Sudan, volume II: London, Harrison and Sons, p 191.

Haynes, C V, 1978, The Nubian Desert: A product of Quaternary climatic cycles, in Greeley $R$ and Black, D, eds, Astracts for the planetary geology field conference on aeolian processes: NASA TM-78, v 455, p 22-23.

in press, Geological evidence of pluvial climates in the El Nabta area of the Western Desert, Egypt, in Wendorf, F and Schild, R, eds, Prehistory of the Egyptian Sahara: New York, Academic Press, in press.

Haynes, C V, Mehringer, P J, Jr, and Zaghloul, S A, 1979, Pluvial lakes of Northwestern Sudan: Geog Jour, v 145, p 437-445.

Haynes, G V, Said, R, and El Hennawi, M, 1977, Quaternary lakes of the Nubian Desert: Paper presented at the 10th congress, INQUA, Birmingham.

Hellstrom, B, 1940, The subterranean water in the Libyan Desert: Sartryck Geog Annaler, nos. 3-4, Stockholm.

International Atomic Energy Agency, 1969, Environmental isotope data, no. 1: World survey of isotope concentrations in preparation (1953-1963): Tech rept ser no. 96, Vienna.

Issawi, B, 1971, Geology of Darb el Arbain, Western Desert, Egypt: Annals Gcol Survey Egypt, v 1, p 53-92.

Klitzsch, E, Weistroffer, K, Sonntag, C, and El Shazly, E M, 1977, Fossil reserves of ground water in the central Sahara: Nat Resources and Development, v 5, p 19-45.

Knetsch, G, Shata, A, Degens, E, Münnich, K O, and Vogel, J C, 1962, Untersuchungen an grundwässern der ost-Sahara: Geol Rundschau, v 52, p 587-610.

Lloyd, J W and Farag, M H, 1978, Fossil groundwater gradients in arid regional scdimentary basins: Ground Water, v 16, no. 6, p 388-393.

Lyons, $\mathrm{H} \mathrm{G}$, 1908, Some unsolved problems of the Nile Basin: Cairo Sci Jour, March.

Myers, O H, 1939, The Sir Robert Mond expedition of the Egypt Exploration Society: Geog Jour, v 93, p 287-291.

Muller A B, 1974, Essai d'application des variations de teneur en radiocarbone dissous a' l'etude des aguiferes libres: Le cas de la nappe phreatique au novel et a l'est du lac Tchad I: PhD thesis, Univ Paris VI.

Münnich, K O and Vogel, J C, 1962, Unterschungen on pluvian Wassern der ost Sahara: Geol Rundschau, v 52, p 611-624.

Murray, G W, 1952, Water beneath the Egyptian Western Desert: Geog Jour, v 118, p 443-452.

Nydal, Reidar and Lövseth, Knut, 1970, Prospective decrease in atmospheric radiocarbon: Jour Geophys Research, v 75, p 2271-2278.

Sandford, K S, 1935, Sources of water in the northwestern Sudan: Geog Jour, v 85, p 412-431.

Shaw, W B K, 1929, Darb el Arbain: The Forty Days Road: Sudan notes and records, $v$ 12, p 63-71.

Street, F A and Grove, A T, 1976, Environmental and climatic implications of late Quaternary lake-level fluctuations in Africa: Nature, v 261, p 385-390.

Tamers, M A, 1967, Radiocarbon ages of ground water in an arid zone unconfined aquifer, in Stout, G E, ed, Isotope techniques in the hydrologic cycle: Am Geophys Union, Geophys mon ser, no. 11, p 143-152.

Wendorf, Fred, Close, A, Schild, R, Said, R, Haynes, C V, Gautier, A, and Hadidi, N, 1977, Late Pleistocene recent climatic changes in the Egyptian Sahara: Geog Jour, v 143, pt 2 , p $211-234$.

Wendorf, Fred, Schild, R, Said, R, Haynes, C V, Gautier, A, and Kobuseiwics, M, 1976, The prehistory of the Egyptian Sahara: Science, v 193, p 103-114. 
DISCUSSION

Vogel: When sampling shallow groundwater near vegetation such as reeds, caution is necessary in interpreting the ${ }^{14} \mathrm{C}$ results. It often happens that the plants introduce modern $\mathrm{CO}_{2}$ into the water by root respiration, thus causing the water to appear younger.

Haas: This is certainly true. From our data it appears, however, that this vegetation effect is small enough as not to significantly influence the $\delta^{14} \mathrm{C}$ data or the conclusions drawn from them. As an example Bir Hussein has the second most active water with an apparent age of $1740 \mathrm{BP}$, but there is no vegetation at all in the vicinity. On the other hand, Bir Nakhlai has a dense root network close to the well and the lowest ${ }^{14} \mathrm{C}$ activity is measured at this well with an apparent age of $11,720 \mathrm{BP}$. The Fox well dates suggest the layering of the ground water without mixing; therefore, sufficient water withdrawal before sampling will bring lower uncontaminated water to the surface. The age layering may also have a different reason as discussed in our paper.

Srdoc: I would like to make a comment and ask a question. The samples of groundwater from Sahara (Northwest Libya) that we have measured have an apparent age close to the lower limit of our dating system $(\approx 40,000$ years $)$ and were always older than $\approx 10,000$ years, which is much older than your dates. We measured water from drilled wells 100 to $500 \mathrm{~m}$ deep. Do you think that the apparent young age of your samples might be due to contamination with atmospheric $\mathrm{CO}_{2}$ ?

The apparent age of recent vegetation you have reported $(>2000$ years old) is somewhat puzzling. Was that an aquatic plant?

Haas: Your work in Libya, involving wells of considerably greater depth presents a different situation, especially different types of aquifers. Artesian wells in the area of our study, mainly around Kharga, with depths of ca $200 \mathrm{~m}$, show ages of 25,000 to 28,000 years; these wells, too, are different from the surface occurrences studied by us.

We do not believe that exchange with atmospheric $\mathrm{CO}_{2}$ causes any major contribution to the ${ }^{14} \mathrm{C}$ content of the waters. All wells are protected by at least $50 \mathrm{~cm}$ of sand, the lower part of which is moist. This forms an effective barrier to air diffusion. The fact that the oldest apparent age came from the most shallow and root infested well (Bir Nakhlai) may be taken as strong support for the above statement. In further support to our claim, the deepest well, Bir Hussein, has the second youngest age.

The aquatic plant in the main well was a bottom mat of calcareous algae (Chara) and a green filamentous algae. It grew in the well before the extensive water withdrawal by a passing caravan took place and may reflest exchange with the atmosphere in the open standing well pond. 